\title{
Analysis of Factors Affecting the Acceleration of Uterine Involution in the Postpartum
}

\author{
$1^{\text {st }}$ Ratna Ningsih \\ Department of Nursing \\ Poltekkes Kemenkes Palembang \\ Palembang, Indonesia \\ ratnaningsih@poltekkespalembang.ac.id \\ Corresponding author: ratnaningsih@poltekkespalembang.ac.id
}

\begin{abstract}
Uterine revolution was a very important process because the mother needs care, and supervision for the recovery of health as before pregnancy. Cases of bleeding are very common and one of the causes is if involution does not proceed normally. This condition causes the mortality and morbidity of puerperal women was still high. The average maternal mortality rate reaches an average of 359 per $100,000 \mathrm{KH}$ [1]. The research objective was to identify the factors that influence the acceleration of uterine involution in postpartum mothers. This research uses analytic survey with cross sectional study design. Sample 38 respondents were taken using non-probability techniques with accidental sampling, and analysis using the chi- square test. The results of the research respondents mostly aged 19-35 years, multiparous parity, exclusive breastfeeding, normal type of labor, respondents mobilized, and most of the rapid uterine involution, and age and type of labor did not affect the acceleration of uterine involution, whereas parity, exclusive breastfeeding, and mobilization affects the acceleration of uterine involution in the puerperium. Suggested the need for monitoring the process of uterine involution to prevent postpartum complications.
\end{abstract}

Keywords: uterine Involution, type of childbirth, age, exclusive breastfeeding, mobilization, parity.

\section{INTRODUCTION}

The process of health recovery during childbirth is very important for mothers after giving birth, because during pregnancy and childbirth there have been physical and psychological changes. Physical changes include soft and sagging ligaments, stretched muscles, enlarged uterus, changed posture as compensation for weight changes during pregnancy, and venous dams on the lower limbs. At the time of delivery the pelvic wall is always stretched and possible damage to the birth canal, and after delivery pelvic floor muscles become loose because it is stretched for so long during pregnancy and childbirth [1].

The puerperium is the period after the mother gives birth to a baby which is used to restore her health back. Restoring health means returning organs that have changed during pregnancy and childbirth (uterine involution). Uterine revolution is a very important process because the mother requires special care, assistance and supervision for the recovery of health as before pregnancy. One indicator in the process of uterine involution is the height of the uterine fundus. If the uterine fundus is above normal then this indicates in the womb something like bleeding occurs, if the blood comes out profusely then the mother loses a lot of blood so that shock can occur until death occurs [2]. Based on the 2012 Indonesian Health Demographic Survey, the average MMR reached 359 per 100,000 $\mathrm{KH}$, the average MMR was much higher compared to the results of the 2007 IDHS which reached 228 per $100,000 \mathrm{KH}$. The causes of maternal death have not changed much in the past, namely postpartum hemorrhage either due to uterine atony or the rest of the placenta (27\%), infection (11\%), preeclampsia/eclampsia (14\%), unsafe abortion (8\%), prolonged parturition (9\%), emboli (3\%), and existing conditions (28\%), and an estimated $60 \%$ of MMR due to pregnancy occur after delivery.

The return of the uterus to the condition before pregnancy both in shape and position due to contraction of the uterine smooth muscles. Factors that can influence the process of uterine involution include maternal characteristics (age, parity), early breastfeeding Exclusive breastfeeding, type of delivery, mobilization, and nutrition. Pregnant women with age below 20 years of uterine muscle elasticity has not been maximized, while age above 35 years of 
muscle elasticity is reduced so that it can be at risk of slowing uterine involution, parity of more than two can be at risk of adverse involution. In pregnant women there are changes in the uterus and also many muscles in the uterus that are stretching. Muscle restoration is done, by breastfeeding Exclusive breastfeeding. The more often mothers breastfeed, the faster the uterus revolution [3]. In post partum mothers with sectio caesarea in general are reluctant to directly breastfeed their babies. Mothers are usually worried because they can cause abdominal pain after surgery and baby sucking can have undesirable effects [4].

The results of Masruroh's research in post partum mothers at Krian Husada Balongbendo Public Hospital in Sidoarjo showed that there was a relationship between IMD and uterine involution [5]. If not breastfeeding, muscle contractions in the uterus are slow and not good. Poor contractions are very likely to experience thrombosis, degeneration of the uterus and endometrium, so the blood vessels become frozen and lead to placental implantation. This also causes the slow release of lochea, causing a prolonged puerperium [1].

According to evidence based updated by UNICEF of 2007 about newborn care for the first hour, namely the baby must get direct contact with the mother's skin immediately after birth for at least one hour the baby is allowed to initiate early breastfeeding [6], [7]. Research conducted by Arifah in Semarang showed that mothers who gave birth normally $87.5 \%$ succeeded in breastfeeding within one hour of giving birth, while mothers who gave birth with sectio caesarea only $4.2 \%$ who succeeded in breastfeeding in the first hour of birth [8]. This type of childbirth so as not to affect the success of breastfeeding for that need help and support from health workers in health services / facilities.

According to Hanida complications of bleeding after childbirth can be prevented as early as possible by carrying out mobilization [9]. Bleeding after childbirth is a frightening condition because in a short time the mother can fall into a state of shock, bleeding that drips slowly but continuously results in maternal death around 50-60\%. Bleeding causes the body's immune system to be reduced so that germs that enter the body multiply through birth canal injuries and the attachment of the placenta in the uterus. This area is a good place for the growth of germs in the body during the puerperium.

Influence of the lowest pressure of the fetus during childbirth, the pelvic wall is always stretched to allow weakness of pelvic floor muscle tone. According to
Hanida to strengthen back pelvic floor muscles after childbirth can be assisted by mobilization [9]. whereas according to Bobak, et.al. mobilization will affect muscle demand for oxygen where oxygen demand will increase means it requires strong blood flow [10]. Like the uterine muscle when stimulated by contraction by mobilization, blood flow will increase and smooth, uterine contractions get better, lochea expenditure becomes smooth, thus affecting the process of uterine involution. Bleeding after childbirth also increases the risk of childbirth infection.

Delay in decreased uterine fundal height is accompanied by an extended period of expenditure of lokhea or excessive and irregular bleeding, the uterus is palpable soft and larger than its normal size [11]. Preliminary study conducted at the private practice midwife of Rejang Lebong district, by conducting interviews with midwives found that during post partum, especially primiparous mothers are still afraid to mobilize and breastfeed early, so mothers experience post partum hemorrhage of approximately $500 \mathrm{ml}$. In the mother palpated soft uterine contractions because there is no stimulation from the outside. The results of interviews from 10 post partum normal mothers randomly mobilized 4 people early, 3 people were afraid of mobilization for fear of perineal sutures, and the age of post partum mothers 24-29 years. Based on the background description, researchers are interested in finding solutions to reduce maternal mortality after delivery, so the researchers tried to conduct research with the topic "Analysis of Factors Affecting the Acceleration of Uterine Involvement in Postpartum Mothers in the Curup Puskesmas Work Area in 2017".

The research objectives were identified factors that influence the acceleration of uterine involution in puerperal mothers in the working area of Curup Puskesmas in 2017, while the specific objectives were identified as the relationship between age, parity, exclusive breastfeeding, type of delivery, and mobilization with accelerated uterine involution.

\section{METHOD}

This study uses analytic survey with cross sectional study design, about the factors that influence the acceleration of uterine involution in postpartum. The sample in this study was obtained using nonprobability techniques with accidental sampling, amounting to 38 respondents with criteria for mothers willing to be respondents and following the research procedures, mothers did not experience complications or complications after delivery, postpartum mothers 
sixth day, and babies born healthy and aterm. Data collection in this study used a questionnaire about age, parity, breastfeeding Exclusive breastfeeding, type of labor, mobilization, while uterine involution by observing the height of the uterine fundus and discharging lochea sanguilenta. Data analysis using chi-square test.

\section{RESULTS}

Table 1. Age Distribution, Parity, Exclusive Breastfeeding, Type Of Childbirth, Mobilization, High Uterine Fundus, Removal of Lochea, And Uterine Involution $(\mathbf{N}=38)$

\begin{tabular}{|c|c|c|c|c|c|}
\hline $\begin{array}{l}\text { No } \\
\text {. }\end{array}$ & & Variable & $\mathrm{F}$ & $\%$ & $\begin{array}{c}\mathrm{p} \\
\text { val } \\
\text { ue }\end{array}$ \\
\hline 1. & Age & $\begin{array}{l}\text { - Productive }(19-35 \\
\text { years) } \\
\text { - No Productive (<19 and } \\
\text { >35 years) }\end{array}$ & $\begin{array}{l}27 \\
11\end{array}$ & $\begin{array}{l}71,1 \\
28,9\end{array}$ & $\begin{array}{l}0,0 \\
96\end{array}$ \\
\hline 2. & Parity & $\begin{array}{l}\text { - Primipara (1 Child) } \\
\text { - Multipara ( } \geq 2 \\
\text { Children) }\end{array}$ & $\begin{array}{l}13 \\
25\end{array}$ & $\begin{array}{l}34,2 \\
65,8\end{array}$ & \\
\hline 3. & $\begin{array}{l}\text { Breastfeed } \\
\text { ing }\end{array}$ & $\begin{array}{l}\text { - Exclusive } \\
\text { Breastfeeding } \\
\text { - Not Exclusive } \\
\text { Breastfeeding }\end{array}$ & $\begin{array}{l}25 \\
13\end{array}$ & $\begin{array}{l}65,8 \\
34,2\end{array}$ & \\
\hline 4. & $\begin{array}{l}\text { Type of } \\
\text { Delivery }\end{array}$ & $\begin{array}{l}\text { - Through Vaginam } \\
\text { - Medical Treatment }\end{array}$ & $\begin{array}{l}28 \\
10\end{array}$ & $\begin{array}{l}73,7 \\
26,3\end{array}$ & \\
\hline 5. & $\begin{array}{l}\text { Mobilizati } \\
\text { on }\end{array}$ & $\begin{array}{l}\text { - Mobilize } \\
\text { - Not Mobilize }\end{array}$ & $\begin{array}{l}27 \\
11\end{array}$ & $\begin{array}{l}71,1 \\
28,9\end{array}$ & \\
\hline 6. & $\begin{array}{l}\text { High } \\
\text { Fundus of } \\
\text { Uterus }\end{array}$ & $\begin{array}{l}\text { - Fast }(<6 \mathrm{~cm} / \text { Hard } \\
\text { Uterus }) \\
\text { - Slow }(\geq 6 \mathrm{~cm} / \text { Soft } \\
\text { Uterus })\end{array}$ & $\begin{array}{l}28 \\
10\end{array}$ & $\begin{array}{l}73,7 \\
26,3\end{array}$ & \\
\hline 7. & $\begin{array}{l}\text { Removal } \\
\text { of Lokhea }\end{array}$ & $\begin{array}{l}\text { - Fast (<7 Days) } \\
\text { - Slow ( } \geq 7 \text { Days) }\end{array}$ & $\begin{array}{l}28 \\
10 \\
\end{array}$ & $\begin{array}{l}73,7 \\
26,3 \\
\end{array}$ & \\
\hline 8. & $\begin{array}{l}\text { Uterine } \\
\text { Involution }\end{array}$ & $\begin{array}{l}\text { - Fast TFU }<6 \mathrm{~cm} \text { Below } \\
\text { the Center, Hard } \\
\text { Uterus, Lokhea } \\
\text { Sanguilenta }<7 \text { Days } \\
\text { - Slow TFU } \geq 6 \mathrm{~cm} \\
\text { Below the Center, Soft } \\
\text { Uterus, Lokhea } \\
\text { Sanguilenta } \geq 7 \text { Days }\end{array}$ & 28 & $\begin{array}{l}73,7 \\
26,3\end{array}$ & \\
\hline & & Total & 38 & 100 & \\
\hline
\end{tabular}

Table 1 shows that the majority of respondents $(71.1 \%)$ are aged $19-35$ years, the majority of respondents $(65.8 \%)$ with multipara parity, most respondents exclusively breastfeeding $(65.8 \%)$, the majority of respondents with normal deliveries $(73.7 \%)$, the majority of respondents mobilized (71.1\%), the majority of respondents decreased TFU quickly $(73.7 \%)$, and most of the respondents' expenditure expenditure was rapid $(73.7 \%)$, mostly involution fast respondent uterus $(73.7 \%)$.
Table 2.

Distribution of Age Relationship, Parity, Exclusive Breastfeeding, Type of Childbirth, Mobilization with Respondents' Uterus Involution

\begin{tabular}{|c|c|c|c|c|c|c|c|c|c|}
\hline \multirow{3}{*}{ No } & \multirow[t]{3}{*}{ Variable } & \multicolumn{4}{|c|}{ Uterine Involution } & \multicolumn{2}{|c|}{ Total } & \multirow{3}{*}{$\begin{array}{c}\text { OR } \\
(95 \% \\
\text { CI) }\end{array}$} & \multirow{3}{*}{$\begin{array}{c}\mathrm{p} \\
\text { value }\end{array}$} \\
\hline & & \multicolumn{2}{|c|}{$\begin{array}{l}\text { Fast TFU } \\
<6 \mathrm{~cm} \\
\text { Below the } \\
\text { Center, } \\
\text { Hard } \\
\text { Uterus, Lo } \\
\text { khea } \\
\text { Sanguilent } \\
\text { a }<7 \text { Days }\end{array}$} & \multicolumn{2}{|c|}{$\begin{array}{l}\text { Slow TFU } \geq \\
6 \mathrm{~cm} \text { Below } \\
\text { the Center, } \\
\text { Soft Uterus, } \\
\text { Lokhea } \\
\text { Sanguilenta } \geq \\
7 \text { Days }\end{array}$} & & & & \\
\hline & & $\mathrm{n}$ & $\%$ & $\mathrm{n}$ & $\%$ & $\mathrm{n}$ & $\%$ & & \\
\hline 1. & $\begin{array}{l}\text { Age } \\
\text { 1. Productiv } \\
\text { e (19-35 } \\
\text { years) } \\
\text { 2. No } \\
\text { Productiv } \\
\text { e } \\
\text { (<19 and } \\
>35 \text { years) }\end{array}$ & $\begin{array}{r}22 \\
6\end{array}$ & $\begin{array}{c}81, \\
5 \\
54, \\
5\end{array}$ & $\begin{array}{l}5 \\
5\end{array}$ & $\begin{array}{l}18,5 \\
45,5\end{array}$ & $\begin{array}{l}27 \\
11\end{array}$ & $\begin{array}{c}10 \\
0\end{array}$ & $\begin{array}{c}3,667 \\
(0,79 \\
-16 \\
99)\end{array}$ & 0,116 \\
\hline & Total & 28 & $\begin{array}{c}73, \\
7\end{array}$ & 10 & 26,3 & 38 & $\begin{array}{c}10 \\
0\end{array}$ & & \\
\hline 2. & $\begin{array}{l}\text { Parity } \\
\text { 1. Primipara } \\
\text { (1 Child) } \\
\text { 2. Multipara } \\
\quad(\geq 2 \\
\text { Children })\end{array}$ & $\begin{array}{c}4 \\
24\end{array}$ & $\begin{array}{c}30, \\
8 \\
96, \\
0\end{array}$ & $\begin{array}{l}9 \\
1\end{array}$ & $\begin{array}{c}69,2 \\
4,0\end{array}$ & $\begin{array}{l}13 \\
25\end{array}$ & $\begin{array}{c}10 \\
0 \\
10 \\
0\end{array}$ & $\begin{array}{c}0,019 \\
(0,00 \\
2-0,1 \\
89)\end{array}$ & 0,000 \\
\hline & Total & 28 & $\begin{array}{c}73, \\
7\end{array}$ & 10 & 26,3 & 38 & $\begin{array}{c}10 \\
0\end{array}$ & & \\
\hline 3. & 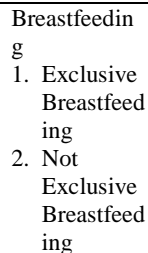 & 23 & $\begin{array}{r}92, \\
0 \\
38, \\
5\end{array}$ & 2 & $\begin{array}{c}8,0 \\
61,5\end{array}$ & $\begin{array}{l}25 \\
13\end{array}$ & $\begin{array}{c}10 \\
0\end{array}$ & $\begin{array}{c}18,40 \\
0 \\
(2,96 \\
2-11 \\
4,307 \\
)\end{array}$ & 0,001 \\
\hline & Total & 28 & $\begin{array}{c}73, \\
7\end{array}$ & 10 & 26,3 & 38 & $\begin{array}{c}10 \\
0\end{array}$ & & \\
\hline 4. & $\begin{array}{l}\text { Type of } \\
\text { Delivery } \\
\text { 1. Through } \\
\text { Vaginam } \\
\text { 2. Medical } \\
\text { Treatment }\end{array}$ & $\begin{array}{c}23 \\
5\end{array}$ & $\begin{array}{c}82, \\
1 \\
50 \\
0\end{array}$ & $\begin{array}{l}5 \\
5\end{array}$ & $\begin{array}{l}17,9 \\
50,0\end{array}$ & $\begin{array}{l}28 \\
10\end{array}$ & $\begin{array}{c}10 \\
0 \\
10 \\
0\end{array}$ & $\begin{array}{c}4,600 \\
(0,95 \\
5-22, \\
160)\end{array}$ & 0,090 \\
\hline & Total & 28 & $\begin{array}{c}73, \\
7\end{array}$ & 10 & 26,3 & 38 & $\begin{array}{c}10 \\
0\end{array}$ & & \\
\hline 5. & $\begin{array}{l}\text { Mobilization } \\
\text { 1. Mobilize } \\
\text { 2. Not } \\
\text { Mobilize }\end{array}$ & $\begin{array}{c}27 \\
1\end{array}$ & $\begin{array}{c}10 \\
0 \\
9,1\end{array}$ & $\begin{array}{c}0 \\
10\end{array}$ & $\begin{array}{c}0,0 \\
90,9\end{array}$ & $\begin{array}{l}27 \\
11\end{array}$ & $\begin{array}{c}10 \\
0 \\
10 \\
0\end{array}$ & $\begin{array}{c}11,00 \\
0 \\
(1,69 \\
7-71, \\
282)\end{array}$ & 0,000 \\
\hline & Total & 28 & $\begin{array}{c}73, \\
7\end{array}$ & 10 & 26,3 & 38 & $\begin{array}{c}10 \\
0\end{array}$ & & \\
\hline
\end{tabular}

Table 2 shows that the age and type of respondent's birth did not affect the acceleration of uterine involution, whereas parity, exclusive breastfeeding, and mobilization affected the acceleration of uterine involution in puerperal mothers in the working area of the Curup Puskesmas in 2017. 


\section{DISCUSSION}

The results of the study on 38 respondents found 27 respondents of productive age, most and almost half of the age of unproductive respondents with rapid uterine involution $(54.5 \%)$ or slow $(45.5 \%)$, and the results of statistical tests using chi-square p value 0.116 means there is no relationship between age and the acceleration of uterine involution. The results are in line with the research of Hadi and Fairus which states there is no relationship between age and the incidence of maternal uterine involution [12]. This is possible because many other factors are associated with uterine involution such as parity, exclusive breastfeeding, mobilization, and others [1].

The results of the study are not supported by Manuaba that age has an influence on complications of pregnancy, childbirth, and the puerperium [13]. Pregnant women with age below 20 years of uterine muscle elasticity is not optimal, the uterus is not ready to accept pregnancy, and psychological women are also not ready to settle down, while age over 35 years often complications occur before and after birth due to reduced or decreased uterine muscle elasticity, causing uterine contractions are not optimal so there is a risk of slowing uterine involution. The results of the study were not supported by the research of Mayasari, Meikawati, and Astuti [14]. and the research of Apriliasari [15].

The results of the study are also known to 25 respondents with multipara parity, and most of the parity of primipara respondents with slow involution (69.2\%). The results of the Fisher's Exact Test statistic are known to be $p$ value 0,000 meaning parity is related to the acceleration of uterine involution. The results of the study are supported by Lisnawaty, Ernawati, and Hasmawati [16]. Mayasari, Meikawati, and Astuti [14]. and research by Apriliasari [15]. which stated that there wss a relationship between parity and uterine involution. Parity affects the process of uterine involution. The process of recovery of the uterus after delivery or involution is different between primipara and multipara. Primipara is shown by the strength of the uterine contractions faster and the palpable uterus, while in multipara uterine contractions and relaxation last longer where the muscles of the uterus are too often stretched, the elasticity of the uterine muscles has decreased, as well as the size of the uterus in primiparous and multiparous mothers have differences so that it influences the process of uterine involution.

The results of the study are also supported by Manuaba [13]. but contrary to research by Liliana [17]. Wahyuni and Nurlatifah [18]. as well as Hadi, and Fairus [12]. which states that there is no significant effect between parity and uterine involution.

Based on the table obtained 25 respondents breastfeeding exclusive breastfeeding, and bivariate analysis also obtained almost all of the respondents who breastfeed exclusively breastfeeding with rapid involution $(92.0 \%)$, exclusive breastfeeding affects the acceleration of uterine involution in postpartum mothers ( $p$ value 0.001). The process of uterine involution is accelerated by the willingness of mothers to breastfeed breast milk. When the baby sucks on the breast milk stimulates the posterior pituitary so that oxytocin can be released, which serves to increase the contraction of smooth muscle around the

alveoli of the ASI gland so that milk can be excreted. Besides oxytocin will also stimulate the uterine muscle to

contract so that it can accelerate the occurrence of uterine involution [13].

The role of early breastfeeding in uterine involution is explained by Roesli, when babies suck breast milk, the muscles in the nipples are stimulated, these stimuli are transmitted to the brain by the nerves, then the brain commands the back of the pituitary gland to release the hormone oxytocin which is carried to the smooth muscles in the breast so that the smooth muscles contract, and the milk is secreted, and in this cell there is more milk production [19]. The hormone oxytocin not only affects the smooth muscles of the breast but the hormone oxytocin will also enter the blood into the smooth muscles of the uterus, and stimulate the uterus to contract. Uterine contractions cause more smooth release of lochea, which means that uterine involution can take place more quickly.

Research results are in line with Wahyuni and Nurlatifah [18]. Lisnawaty, Ernawati, and Hasmawati [16]. and Hadi and Fairus [12]. research. The role of early breastfeeding in uterine involution is explained by Roesli, when babies suck breast milk, muscles, in the nipples are stimulated, these stimuli by nerves are transmitted to the brain, then the brain commands the back of the pituitary gland to release the hormone oxytocin which is carried to the smooth muscles of the breast so that the smooth muscles contract, and milk is released, and in these cells there is production ASI again [19]. The hormone oxytocin not only affects the smooth muscles of the breast but the hormone oxytocin will also enter the blood into the smooth muscles of the uterus, and stimulate the uterus to contract. Uterine contractions cause more smooth release of lochea, which means that uterine involution can take place more quickly. 
The research results are in line with Wahyuni and Nurlatifah's research [18]. Lisnawaty, Ernawati, and Hasmawati [16]. Hadi and Fairus research [12]. and Masruroh [5]. but not in line with Liliana's research [17].

This study also found the results of 28 respondents with normal delivery, half the respondents with the act of experiencing involuntary uterus sooner or later $(50 \%)$, and the results of the Fisher's Exact Test statistical test found $\mathrm{p}$ value of 0.090 means that the type of delivery did not affect the acceleration of uterine involution in postpartum mothers.

According to Winkjosastro (2014) states that all types of childbirth will cause uterine contractions for the process of uterine involution, but the speed of the involution process is different. In labor with sectio secarea there will be cuts in nerves, blood vessels and lymph vessels which will affect the process of uterine involution. According to Mochtar, post partum mothers with caesarean section are generally reluctant to directly breastfeed their babies [4]. Mothers are usually worried because it can cause postoperative abdominal pain and baby suction can have undesirable effects so that uterine pinvolution is slow. The incompatibility of research results with the theory is possible because the acceleration of the process of uterine involution can still be maximized with other influential factors such as parity, exclusive breastfeeding, mobilization.

Based on the table, the results obtained from 27 respondents mobilized, and all respondents who mobilized with rapid uterine involution (100\%), whereas all respondents who did not mobilize with slow uterine involution $(90.9 \%)$. Statistical test results using chi-square obtained $\mathrm{p}$ value 0,000 means that mobilization affects the acceleration of uterine involution in postpartum mothers in the work area of Puskesmas Curup. According to Hanida, complications of bleeding after childbirth can be prevented as early as possible by carrying out mobilization [9]. The purpose of mobilization is to facilitate the release of lochea, accelerate uterine involution, facilitate the functioning of the gastrointestinal organs and urinary organs, facilitate the circulation of blood circulation [4]. Bleeding after childbirth is a frightening condition because in a short time the mother can fall into a state of shock, bleeding that drips slowly but continuously results in maternal death around 50-60\%.

According to Bobak, et.al., mobilization will affect muscle demand for oxygen where oxygen demand will increase means it requires strong blood flow [10]. As with the uterine muscle when stimulated by contraction by mobilization, blood flow will increase and smooth, uterine contractions get better, expenditure of the lokhea becomes smooth, thus affecting the process of uterine involution. Mobilization increases the contractions and retractions of the uterine muscles after giving birth. These contractions and retractions are needed to clamp broken blood vessels due to placental detachment and are useful for removing unnecessary uterine contents. The existence of continuous contractions and retractions causes disruption of blood circulation in the uterus resulting in muscle tissue lacking the necessary substances, so that the size of the muscle tissue becomes small. With this process, mothers who mobilize have decreased uterine fundus faster and uterine contractions stronger than mothers who do not mobilize [20]. According to Kautsar's research, early mobilization can reduce the lochea dam so that it can accelerate the process of uterine involution [21].

\section{CONCLUSION}

Most respondents aged 19-35 years, most respondents with multipara parity, most respondents exclusively breastfeeding, most respondents had normal deliveries, most respondents mobilized, and most of the respondents' uterine involution was rapid.

Statistical test results used chi-square that age and type of respondent's birth did not affect the acceleration of uterine involution, whereas parity, exclusive breastfeeding, and mobilization influenced the acceleration of uterine involution in postpartum mothers in the working area of the Curup Puskesmas in 2017.

Suggestion: health workers to be more active and intensive in monitoring postpartum mothers so that mortality or morbidity rates for post partum mothers can be reduced.

\section{ACKNOWLEDGMENT}

The author is grateful to the unit of research and community services at Department of Nursing Poltekkes Kemenkes Bengkulu for assisting the realization of an independent research scheme in 2017

\section{REFERENCES}

[1] H. W. Ilmu Kandungan. Jakarrta: Yayasan Bina Pustaka Sarwono Prawirohardjo; 2014.

[2] M. R. Keperawatan Maternitas: Kesehatan Wanita, Bayi dan Keluarga. 18th ed. Jakarta: EGC; 2011.

[3] R CL\& D. Maternal Newborn Nursing: The Critical Components of Nursing Care. Philadephia: F.A. Davis Company; 2010

[4] R. M. Sinopsis Obstetri: Obstetri Fisiologi, Obstetri 
Patologi. Jakarta: EGC; 2012.

[5] S. M. Hubungan Inisiasi Menyusui dini dengan Involusi Uteri pada Ibu Post partum di RSU Krian Husada Balongbendo Sidoarjo. 2010

[6] UNICEF. Initiation of Breasfeeding by Breast Crawl. India: Unicef Maharastra 19, Harish Enterprises Parsee Panchayat Road, Andheri; 2007.

[7] D. ARE\& W. Hubungan Inisiasi Menyusui Dini Terhadap Penurunan Tinggi Fundus Uteri Ibu Nifas. 2009.

[8] I.N. A. Perbedaan Waktu Keberhasilan IMD antara Persalinan Normal dengan Caesar di Ruang An Nisa RSI Sultan Agung Semarang. Universitas Diponegoro, 2009.

[9] Hanida. Faktor-Faktor yang Berhubungan dengan Involusi Uteri Postpartum Pervaginam di Rumah Sakit Ibu dan Anak Pemerintah Aceh. Stikes U'Budiyah Banda Aceh, 2012.

[10] Bobak I.M., Lowdermilk, D.L., Jensen, M.D., \& Perry SE. Maternity Nursing. 4th ed. Mosby-Year Book Inc; 2010.

[11] H. V. Buku Ajar Asuhan Kebidanan. 4th ed. Jakarta: EGC; 2010.

[12] Yusro Hadi M. MF. Faktor- faktor yang Berhubungan dengan Involusi Uterus pada Ibu Post Partum di Wilayah Kerja Puskesmas Ketapang Lampung Utara. Jurnal Kesehatan Metro Sai Wawai 2014;VII:2-8.

[13] Manuaba I.A.C., Manuaba I.B.G.F \& MIBG. Ilmu Kandungan, Penyakit Kandungan, dan KB. Jakarta: EGC; 2013.

[14] Mayasari FF, Meikawati W, Astuti R. Faktor-Faktor yang Mempengaruhi Involusi Uterus (Studi Kasus) di BPM Idaroyani dan BPM Sri Pilih Retno Tahun 2014. Jurnal Kesehatan Masyarakat Indonesia 2015;10:17-22.

[15] Apriliasari D. Hubungan Usia Dan Paritas Dengan Kejadian Involusi Ibu Nifas Di BPS Mojokerto. Lap Penelit 2015.

[16] Lisnawaty, Ernawati, Hasmawati. Faktor - Faktor Yang Mempengaruhi Involusi Uterus Pada Ibu Post Partum Di Rumah Sakit Khusus Daerah Ibu Dan Anak Pertiwi Makassar. Jurnal Ilmiah Kesehatan 2015;7:565-71.

[17] Liliana A. Pengaruh Paritas Dan Perilaku Imd Dengan Involusi Uteri Pada Ibu Postpartum Di Rsud Panembahan Senopati Bantul. J Keperawatan Respati Yogyakarta 2019;6:518. https://doi.org/10.35842/jkry.v6i1.296.

[18] Wahyuni N, Nurlatifah L. Faktor -faktor yang Mempengaruhi Proses Involusi Uterus pada Masa Nifas di wilayah Kerja Puskesmas Mandala Kabupaten Lebak Propinsi Banten Tahun 2016. J Med 2017;4:167-76.

[19] U. R. Breast Feeding with Confidence. Jakarta: Alex Media Komputindo; 2008.

[20] Martini. Hubungan IMD dengan TFU Ibu Post Partum Hari Ke-7 di Wilayah Kerja Puskesmas Kotabumi II Lampung Utara. Universitas Indonesia, 2012.

[21] R. K. Hubungan Antara Mobilisasi Dini dengan Involusi Uteri pada Ibu Nifas di BPS Vinsentia Ismijati. Stikes Insan SeAgung Bangkalan. Surabaya, 2011. 